[3] Herbst, P., Cheah, U. H., Richard, P. R., Jones, K. (Eds.) (2018). International Perspectives on the Teaching and Learning of Geometry in Secondary Schools. Springer International Publishing, VI, 386. doi: http://doi.org/10.1007/978-3-319-77476-3

[4] Hawes, Z., Moss, J., Caswell, B., Naqvi, S., MacKinnon, S. (2017). Enhancing Children’s Spatial and Numerical Skills through a Dynamic Spatial Approach to Early Geometry Instruction: Effects of a 32-Week Intervention. Cognition and Instruction, 35 (3), 236-264. doi: http://doi.org/10.1080/07370008.201 7.1323902

[5] Frick, A., Newcombe, N. S. (2012). Getting the big picture: Development of spatial scaling abilities. Cognitive Development, 27 (3), 270-282. doi: http://doi.org/10.1016/j.cogdev.2012.05.004

[6] Harris, J., Newcombe, N. S., Hirsh-Pasek, K. (2013). A New Twist on Studying the Development of Dynamic Spatial Transformations: Mental Paper Folding in Young Children. Mind, Brain, and Education, 7 (1), 49-55. doi: http://doi.org/10.1111/mbe.12007

[7] Kelman, M. S., Murashyn, O. H. (2008). Zahalna teoriia derzhavy i prava. Kyiv: Kondor, 477.

[8] Honta, V. (2015). Algorithmization tests development Algorithmization tests development orithmization tests development of spatial imagination. Motrol. Commission of motorization and energetics in agriculture, 17 (8), 61-66

[9] Peters, M., Laeng, B., Latham, K., Jackson, M., Zaiyouna, R., Richardson, C. (1995). A Redrawn Vandenberg and Kuse Mental Rotations Test - Different Versions and Factors That Affect Performance. Brain and Cognition, 28 (1), 39-58. doi: http://doi.org/10.1006/brcg.1995.1032

[10] Maresch, G., Fuchs, K. J., Plangg, S., Zöggeler, M. (2018). Wirkung unterschiedlicher Darstellungsformen bei Aufgaben zur mentalen Rotation. Mathematik im Unterricht, 9, 75.

\title{
NOMADISM AS A WAY OF BEING OF THE IMMIGRANTS AND INTERNALLY DISPLACED PERSONS
}

\author{
Marina Kolinko \\ Department of Philosophy \\ Vasyl Stus Donetsk National University \\ 21 600-richya str., Vinnytsia, Ukraine, 21021 \\ mkolinko09@gmail.com
}

\begin{abstract}
The article presents the innovatory understanding of the nomadic strategy of human being in the transitional condition. The aim of the article is to determine the role of the nomadic being way in the social group of internal migrants. It is substantiated, that aims and actions of a nomad are directed on creating new ways of realization and conceptualization of variants of nomadic being. It is explained, that a nomad doesn't go by the way, offered by traditional types of activity, but searches innovatory ways of realization, doesn't stop on deciphering of traditionally existing being senses, but produces them him/herself. A subject, living in a space of "boundaries" is deprived of the settled comfort, he/she searches for a possibility of balance and harmony, social recognition and improvement of own life conditions in the movement and change. The culture of choice, formed by the logic of the modern market, gives a nomad resources for regulating the own freedom degree. Nomadic instruments correspond to the migrants' way of life. Digital nomadism creates stimuli for the active life and adaptation to new conditions of different groups of migrants.
\end{abstract}

Keywords: internally displaced persons (IDP), immigrants, boundary, nomadism, digital nomad.

\section{Introduction}

Among topical, acute social problems that need philosophical understanding, a leading place is occupied by the theme of transformation of socio-cultural interactions in the dynamically changeable world. "Boundary" challenges of today explain the interest to anthropological and socio-cultural aspects of the theme of boundary and transitional condition of being, caused by migration processes, wars, political and religious events in the world. Such challenges include military 
conflicts, for example, one in the East of Ukraine, in which connection Ukraine occupies the ninth place in the world by the number of internally displaced persons. Another aspect of the problem of transition is connected with a fact that modern technological rhythms produce the new type of cultural being - contemporary nomads. A place and cultural significance of nomadism is a subject of the active international scientific discussion. The great empirical material is accumulated about nomadic cultures and nomadism, but today nomadism gains absolutely another space and content, solves new socio-philosophical tasks.

A human in his/her self-realization may be characterized by the condition of boundary being. It is underlined by Martin Buber [1], when insists on determining relations between subjects in the space of "boundaries" as a constitutional construction of being. Georg Zimmel [2] initiates a discussion about Another, separated from the traditional collective, forming new rules and practices. Bernhard Waldenfels [3] uses a term "iterculturality" and describes a form of decentered relations, considers "between" as an interpretation of practices of dialog and tolerance. The modern philosopher-postcolonialist Eva Aldea also has a tendency to deterritorialization "We inhabit a world where a simple relationship to the place we live in no longer exists, not either for ourselves or for our neighbours. We are exposed daily to people that cross national boundaries, defy language barriers and unsettle cultural traditions" [4]. Professor in the Humanities at Utrecht University Rosi Braidotti analyzes the process of formation of a nomadic subject and makes a conclusion that "philosophical nomadic thought contributes to cosmopolitan community building against narrow nationalistic practices and it sustains multiple ecologies of belonging" [5, p. 408].

The English-speaking scientific environment includes several notions that designate a boundary, so studies of different kinds of boundaries appear: border studies, boundary studies, frontier studies. The study of nomadism in our article is realized in the context of boundary studies - socio-cultural boundaries. It is impossible to describe it using instruments of the modern topology, in the context of positivist paradigm of ideas about space and time, modern model of subjectivity. The concept was presented by G. Deleuze and F. Gvattari "Capitalism and schizophrenia. Thousand plateaus" [6] for describing a principle of deconcentration of a subject in the changeable space. The understanding of the socio-cultural reality as a set of local, singular orders is elaborated most reasonably and successively in the nomadic theory of G. Deleuze and F. Gvattari. At supremacy of the controlled and managed way of life, a nomad was interpreted as chaos. The cultural space, created by post-modern thinking, is structured principally otherwise. A model of such thinking and culture that represents it is symbolized by a net, labyrinth, rhizome. As a result of the growing popularity and importance of nomadism, this phenomenon needs philosophical reflection and culturological assessment.

\section{Aim of research}

To determine typical features of nomadic way of being and to explain its role in the cultural environment of resettlers and migrants.

\section{Materials and Methods}

A theoretical method that determined the movement and logic of our scientific work is phenomenology - study of the endured experience and life world, accented on a space, where a human lives. A base research instrument in investigations of nomadic being of resettlers is the post-structuralist methodology of G. Deleuze and F. Gvattari. The comparative method gives a possibility to realize the comparative analysis of the traditional settled way of life and the nomadic one. Methods of information collection for scientific conclusions are the analysis of open sources and also conversations with resettlers and included observation of the author of the research.

\section{Results}

Digital nomadism becomes a mainstream of the modern cultural and economic life. The transitional social condition of resettlers motivates to actualization of such features as vigor, resoluteness, self-respect, ability to understand novelty, to familiarize unknown social spaces, to defend democratic rights and ideals of freedom. In this connection the social group of resettlers 
has a great resource potential in understanding and assimilating new socio-cultural and economic tendencies, especially, digital nomadism.

\section{Discussion}

\section{1. Nomadism as a new tendency of transcultural being}

From the remotest times being of a cultured human is rooted in the historical experience and certain geographic space, grows from it, can’t ignore it. But modern philosophical-anthropological investigations are concentrated on the opposite tendency - a boundary character of human being. The transitional condition may be an existential choice, or provoked by the social crisis, ecological catastrophe, military actions at a dwelling territory, so connected with not a desire, but constraint, may be situational or distributed on a long period of being. The human experience becomes transgressive in such case. At that transgression relates not so much to the social boundary, but to the boundary character of a human him/herself, as the Russian scientist Sofia Kashtanova notes: "Transgression as overcoming of a boundary, that seems to be unshakable from the first sight, is really expanded in the internal experience of a human, is a feeling of the own boundary character, and this feeling is the more acute, the farther a human steps beyond his/her limits" [7, p. 157]. Transgression becomes an active motivation to familiarization and cognition of new economic, cultural, social practices.

From the other side, an image of self-identity, closed, geographically localized national cultures, goes to the past. They are replaced by the epoch of transculturalism that actualizes such notions as "boundary", "frontier", "nomadism". If the historical role of frontier was (and still being) in protection of communication safety and control over the movements of migrants and dwellers of frontier zones, processes of transculturalism, that is discrepancy of cultures with their spatial-temporal localization and text frames, actualize an event of exit beyond boundaries, softening and blurring of frontiers. A significance of these processes "consists in the production of a new form of subjectivity, a non-territorial subjectivity or, better still a deterritorialized subjectivity able to elude, or at least, to decrease the effects of power it would otherwise originate" [8, p. 10]. At that there are observed different practices of cultural transgression. The prefix trans as a movement through, across the space, reveals a cultural dynamics that may be expressed in practices of overcoming cultural limits, blurred identity, domestication of symbols and rules of another cultural space. The problem field of transculturalism indicates that the global culture cannot be mechanically constructed of different elements. It lives, taking and dissolving in itself wandering signs and symbols of different cultural spaces that not always can be compared, strives for the dynamic balance. Such its movement refers us to problems of the cultural topology, especially, configuration of new cultural limits, not coincided with geographic and ethnic ones, their intellectual nature and location that don't correlate with national borders.

The conception of digital nomadism was developed in works of Western intellectuals. For example, Zigmund Bauman thought that "in the same way as the pilgrim was the most fitting metaphor for the modern life strategy preoccupied with the daunting task of identity-building, the stroller, the vagabond, the tourist and the player offer jointly the metaphor for the postmodern strategy moved by the horror of being bound and fixed" [9, p. 25-26]. The principal difference between digital nomadism and other migration strategies is that a nomad is dissolved in the space of his/her activity, without accepting boundaries and codes. "Nomadism, as Deleuze and Guattari understand it, doesn't require moving around. You can sit still and be a nomad. Nomadism is a way of being. It involves refusing to be tied down by set categories and definitions. It is driven by a desire to experiment and explore, to learn, grow, and boldly venture forth on creative lines of flight" [10]. A rhizome model of the nomadic culture, offered by G. Deleuze instead of a settled one, marked a set of post-modernism on the presumption of destruction of traditional ideas about the structure as a stably defined one, on the radical alternative to static and closed linear structures with a rigid axial orientation. Plural connections of the modern cultural space exist, but they are structureless, confused, continuously torn, creating symbioses of "familiar-strange", beginning new stages of transformation. Such transcultural process provides relations of openness, based on mutual information, orientation on the diversity of cultural being. Based on reflections of G. Deleuze about 
an individual as an undefiled, floating, flowing, such that joins, opens a game of differences as a contrary to the abstract subjectivity of transcendentalism, Vadim Palaguta makes a conclusion about the nomadic subjectivity as "polysubjectivity by its essence that a priori provides ontology of Another as its constituting base" [11, p. 212].

Nomadic being, world understanding and thinking are opposed to the simply centered systems, it slides on the content surface, without stopping anywhere. Challenges of nomadic being collide with strivings for wholeness and integrity of the national culture that as a result must doubt itself, but it is usually unready for that. So, its response is an objection, non-acceptance and, as a result, a conflict. Frontal changes of the cultural space are accompanied by the confrontation of heterogenic elements in the new forming tradition. Complicated configurations of the multicultural Ukrainian space are formed also in the modern logic of the game between the center and periphery, and must take into account transcultural and nomadic tendencies of the post-modern world. The Ukrainian society only begins to understand the importance of digital nomads' practices. The author tried to study the phenomenon of nomadic being by the method of included observation and conversations with Ukrainian resettlers.

\section{2. Isolation from home - condition for nomadism actualization among resettlers}

It must be accepted, that migration processes are a serious challenge for the modern world. Globalization discourses result in a change of repertoires of cultural rules, political scenarios and identities and potentially can deprive migrants of a possibility to work, make new types of the social space and communication unavailable for them as for an undesirable social group. For example, Rūta Sutkute in her research touches the problem of being and perception of migrants and offers the analysis of important initiatives, "that help refugees in full, and what is more, they educate society about integration of refugees" [12, p. 35]. Just marginalization of migrants' being can push them to searching for deterritorialized ways of realization.

One of modern social groups in Ukraine, inclined to the nomadic style is internal resettlers from Crimea and Donbas. Difficult life conditions and striving for integration in the new sociocultural environment need from them such qualities as social responsibility, entrepreneurial activity, stress-resistance. Groundlessness is painful and complicated for identification processes. Blurring of identification that resettlers face with correspond to characteristics of the nomadic image. Obviously, the great part of resettlers like most Ukrainian people is engaged in traditional types of activity that favors their integration in new communities. But digital nomadism is considered as a promising resource for improving their welfare. Temporary homelessness provokes their search for "not home" forms of communication, pushes to improving skills of activity in the virtual space of the information environment, to using profits and bonuses of the mobile existence. Mobile working places become more and more popular and show a way out in a situation, when a person loses his/her native home, habitual environment, roots. A labor activity without a tight schedule and territorial bind to a working place corresponds to these conditions. The way of life of successful migrants forces to doubt the stability of rules of the settled life, necessity in territorial fixation for a modern human. For not understanding deterritorialization of a subject as escape and ignorance, a community must realize that the living space organization on the "ancestors' land" goes to the past and that "this escape is not merely passive; on the contrary, it also involves an active creation of lines of flight, a production of new spaces, possibilities and alternative territories and entails the cutting on the "sticky" surface of the majoritarian semiotic orders and the creation of new semiotic configurations, which, in turn, must obviously not be absolutized" [8, p. 14-15]. A tendency of the modern world is a fact that many formerly demanded professions lose their social priority, actuality or even disappear at all, the ratio between the settled way of life and nomadism in economy gradually changes in favor of the latter. The American organization MBO Partners in 2018 conducted the study of digital nomadism and readiness of the society to it. "4.8 million Americans described themselves as digital nomads. Among traditional U.S. workers, $27 \%$ said they "might" become digital nomads in the next 2-3 years, and $11 \%$ said they planned to" [13]. The organization plans to fix deterriorialization tendencies further. The need in the sociological analysis of digital nomadism that is a prospect of our study is also urgent in Ukraine. 
The sphere of internet-marketing gives a promising field for the activity of digital nomads that is conditioned by the active development of information-communication technologies and spread of freelance as an activity type. Resettlers are a vanguard group of these processes, because main signs of their life style are considered as uncertainty, unsteadiness, changeability. Just these features of routine life that release from the pressure of traditional structures allow resettlers to activate themselves and to realize their strivings and hopes for improving life, welfare, social status in virtual activity forms. Their behavior is distinguished by higher mobility comparing with settlers of cultural hinterlands, creation of new nets and streaming forms of social contacts.

A confrontation with the new reality needs both material and psychological resources. The choice of a nomad's way is connected with certain risks. A risk of deterritorialization is in a fact that a nomad has no home, no built route, no destination point. An opposition to terrirorialization leaves a nomad beyond the normative political space, in "a country "nowhere" that can also become a contrapolitical or antipolitical space", writes Étienne Balibar [14, p. 192], reminding M. Foucault's heterotopia. But is this condition acceptable under conditions of the tragic situation of Ukrainian today? At that, tearing him/herself from the ground, sliding along the virtual ocean, a human nevertheless wants to have an own "destination port". Deterritorialization of the working space cannot be expanded on the whole routine, creating a human without kith or kin, deprived of the close environment and home comfort. At the same time a free schedule needs hard self-organization, culture of care about oneself, calm reaction to loneliness. These risks become advantages, when a human is taught to support a balance between labor and leisure, personal life and public activity. A strategy of balance between public and private helps resettlers to minimize risks of the unsuccessful adaptation to the new social environment. Such thought about migrants is expressed by Ceren Sezer in the article "Public life, immigrant amenities and socio-cultural inclusion: the presence and changes of Turkish amenities in Amsterdam" [15].

Nomadic practices are activated by intensifying routine accents on leisure and globalization processes. Nomadism introduces the principle of freedom in routine life. The problem is how to form practical conditions for the effectiveness of this new form of subjectivity that perceives the world as a general open space, without limitations and strict structurization, as a net of actions and a flow of communication. In this context digital nomadism is one of most discussed themes. The appearance of new communication nets and channels results in changing communication forms and styles, content and functional sides of life activity, not stable qualities of a subject, but the space of relations and skills to organize them are taken into account. Digital nomads are a cultural minority for today, but just today they influence great flows of the working force, capital, found normative and ethic development prospects for both professional and cultural communication, gradually becoming a nomadic elite that breaks its connections with a native territory, cultural roots, even with ones, who live besides nomads. Nomadic practices test normality of the cultural world, stability of its rules, mechanism of inclusion/exclusion to/of it, their flexibility and ability to react to new challenges sensitively. Due to modern communication means the intensive construction of the new reality takes place today. In the context of the general life trajectory that on the one hand is detail planed, on the other one is provided more and more difficultly under modern conditions, migration strategies are ranged with the same cautions. But the categorical statement about alienation of a nomad from his/her close environment may be debated. It is contested by author's conversations with resettlers-freelancers, who live in Kyiv, Vinnitsa, Chernihiv and Poltava regions, by the analysis of talks of migrants in social networks and also by information of public organizations for working with IDP, that give humanitarian help and realize long-term projects on the development ("Human in trouble", Norwegian council on refugees (NRC), Karitas Ukraine, "Donbas SOS", "East SOS", "Crimea SOS", "Non-indifferent women of Donbas"). The image of a comfort, accustomed house, protected by big walls from the scarring, continuously changing world, goes to the past, completeness stops to be a criterion of social efficiency, flexibility of open communication and creative experience become more and more important. A feeling of home under circumstances of its territorial loss transfers to understanding of the spiritual space of the home world, for example, virtual co-presence of the native circle due to modern means of communication and connection. 
Actors of nomadic practices translate images of other cultures in the home world, motivate to elaborating strategies of tolerance, hospitality of the accepting world, cultural recognition. But the review of the research literature, for example, $[9,12,14]$ doesn't allow to state confidently that nomadic practices inevitably favor harmonization of inter-cultural communication and social consent. The proof of this hypothesis and theoretical reflection on the question: "under what conditions nomadic practices favor the development of tolerance and not xenophobia" depends on further empirical studies.

\section{Conclusions}

1. At constructing the spatial scheme of the world, the toposes "home" and "boundary" play the structure-creating role. Home with its order, where everything has its place, including a person, gives a feeling of the reliable domestic being-in-the world. The limited world of the period of the settled way of life serves a human as a strong fence that doesn't motivate him/her to questioning and studying him/herself. The boundary fixation not only underlines a territory of the home world, but also produces reflections about an image of the future cultural Home as an open net of cultural spaces, crossed with moving boundaries. There appear diverse practices of cultural, economic, social transgression. They actualize transculturalism, exit of subjects beyond their historical and territorial limits. The closed cosy space is replaced by the open one of the cultural horizon. Under such conditions nomadism that indicates a perspective of understanding the dynamics of socio-cultural changes becomes an actual form of social being. The more a human strives for mastering mobile activity and leisure types, the stronger his/her life is connected with the virtual way of self-realization, the swifter he/she moves away from the settled way of life and approaches to the nomadic one.

2. The article for the first time proves that nomadism is a socio-cultural way out of economic solution of problem being of resettlers and migrants. It has been studied, that the striving for safety and comfort that resettlers were deprived of as a result of the forced leaving of a domestic territory, compels to search for new forms of life experience and realization. Mastering of skills in the sphere of IT-technoogies actualizes digital nomadism as a way of resettlers' adaptation to the new cultural conditions. The essential integrating potential is in the resettlers' movement. Internally displaced persons create the environment that motivates to reflection and realization of strategies of civic solidarity and cultural dialog, to testing of own limits and consolidation possibilities by the society.

\section{Acknowledgments}

I express my gratitude to the Vasyl' Stus Donetsk National University and the Department of Philosophy, where I have been working for twenty years and my professional interests have been formed. Teachers and students of the university sincerely shared their knowledge and experience as immigrants.

\section{Financing}

The article was prepared within the state budgetary research project "Socio-philosophical reflection of ways of solving the conflict in the East of Ukraine".

\section{References}

[1] Buber, M. (2014). Between Man and Man. Martino Fine Books, 220.

[2] Zimmel, G. (2008). Ekskurs o chuzhake. Sotsiologicheskaya teoriya: Istoriya, sovremennost, perspektivy. Al'manakh zhurnala "Sotsiologicheskoye obozreniye". Saint Petersburg, 7-13.

[3] Waldenfels, B. (1995). Svoya i chuzhaya kultura. Paradoks nauki o "Chuzhom". Logos, 6.

[4] Aldea, E. (2014). Nomads and migrants: Deleuze, Braidotti and the European Union in 2014. Open Democracy. Available at: https://www.opendemocracy.net/can-europe-make-it/eva-aldea/nomads-andmigrants-deleuze-braidotti-and-european-union-in-2014 Last accessed: 18.02.2019

[5] Braidotti, R. (2010). Nomadism: Against Methodological Nationalism. Policy Futures in Education, 8 (3-4), 408-418. doi: http://doi.org/10.2304/pfie.2010.8.3.408 
[6] Delez, Zh., Gvattari, F. (2010). Kapitalizm i shizofreniya: Tysyacha plato. Saint Petersburg: U-Faktoriya; Astrel, 895.

[7] Kashtanova, S. (2016). Transgressiya kak sotsialno-filosofskoye ponyatiye. Saint Petersburg: SPbGU, 203.

[8] Simone, A. (2014). Territory and Subjectivity: the Philosophical Nomadism of Deleuze and Canetti. Minerva - An Open Access Journal of Philosophy, 18, 1-26.

[9] Bauman, Z.; Hall, S., Du Gay, P. (Eds.) (2011). From pilgrim to tourist - or a short history of identity. Questions of cultural identity. Thousand Oaks: Sage Publications, Inc, 18-36. doi: http://doi.org/ $10.4135 / 9781446221907$

[10] Rayner, T. (2013). Lines of flight: Deleuze and nomadic creativity. Philosophy for change. Available at: https://philosophyforchange.wordpress.com/tag/nomadism Last accessed: 19.02.2019

[11] Palaguta, V. I. (2010). Samoidentifikatsiya sotsialnogo subyekta v diskursivnykh prostranstvakh. Dnepropetrovsk: Innovatsiya, 440.

[12] Sutkute, R. (2019). Shaping of the public discourse on refugees in social media: "Refugees welcome Lithuania." EUREKA: Social and Humanities, 1, 35-52. doi: http://doi.org/10.21303/2504-5571. 2019.00824

[13] Pofeldt, E. (2018). Digital Nomadism Goes Mainstream. Forbes Media LLC. Available at: https://www.forbes.com/sites/elainepofeldt/2018/08/30/digital-nomadism-goes-mainstream/\#15245a9a4553 Last accessed: 10.01.2019

[14] Balibar, E. (2009). Europe as Borderland. Environment and Planning D: Society and Space, 27 (2), 190-215. doi: http://doi.org/10.1068/d13008

[15] Sezer, C. (2018). Public life, immigrant amenities and socio-cultural inclusion: the presence and changes of Turkish amenities in Amsterdam. Journal of Urban Design, 23 (6), 823-842. doi: http://doi.org/ $10.1080 / 13574809.2018 .1475221$ 